\title{
Larval swimming and postlarval drifting behavior in the infaunal bivalve Sinonovacula constricta
}

\author{
Wen-Xiong Wang*, Zhen-Zu Xu \\ Department of Oceanography, Xiamen University, Xiamen, 361005, Fujian, China
}

\begin{abstract}
Under laboratory conditions swimming behavior of larvae of the infaunal bivalve Sinonovacula constricta was dominated by a vertically oriented helical spiral with intermittent sinking. enabling larvae to regulate their vertical position in the water column. Instantaneous swimming velocities ranged between 0.4 and $0.7 \mathrm{~mm} \mathrm{~s}^{-1}$ for veliger and veliconcha larvae, these values were directly comparable to those recorded for other marine bivalve larvae. Swimming activity due to ciliary beating in the velum represented a negligible fraction of total energy expenditure. Postlarval drifting was first observed on Day 9 after larval metamorphosis and settlement and continued for about 1 mo. A major mechanism underlying postlarval drifting was the secretion of a single byssus thread which was at least 50 times longer than the body size. Calculations indicated that the viscous drag of the elongated thread was about 6.7 times greater than the viscous drag of the body, thus providing a hydrodynamic basis for postlarvae to remain suspended in the water column. Environmental factors that increased postlarval drifting included lowered temperature, starvation and decreased light lllumination. There were at least 3 peaks of postlarval drifting, especially on Day 26 after the larval settlement; these data were consistent with direct field observations. Combination of both physical (e.g. tidal current transport) and biological (e.g. byssus thread) processes are critical in determining the secondary pelagic drifting of $S$. constricta postlarvae
\end{abstract}

KEY WORDS: Behavior - Larval swimming - Postlarval drifting - Infaunal bivalve . Sinonovacula constricta

\section{INTRODUCTION}

The early life history of many marine bivalves is characterized by 2 distinct pelagic phases, including a primary larval stage and a secondary bysso-drifting postlarval stage. Both stages have been identified as important components of meroplankton in many coastal and estuarine waters (Thorson 1950, Butman 1987). Larval dispersal and retention within estuaries are directly dependent on larval distribution and ability to regulate position in the water column. Various swimming mechanisms such as ciliary beating or muscular propulsion are required to maintain the position of larvae in the water column (Chia et al. 1984). Many

\footnotetext{
- Present address: Marine Sciences Research Center, State University of New York, Stony Brook, NY 11794-5000, USA.

E-mail:wwang@pro.msrc.sunysb.edu
}

marine invertebrate larvae are able to control their vertical position by swimming, but are unable to control their horizontal position due to their weak swimming abilities and strong horizontal currents (Wood \& Hargis 1971, Mileikovsky 1973, Mann 1988). Studies on larval swimming activity and the behavioral responses to different factors (e.g. light, gravity and pressure) can provide a basis for understanding larval depth regulation in natural environments (Sulkin 1984)

In marine bivalves, the presence of a secondary pelagic life after larval settlement is well recognized (Bayne 1964a, de Blok \& Tan Maas 1977, Butman 1987. Armonies 1992). Postlarvae are able to re-enter the water column either by passive erosion of substrate or by active movement before finally finding a permanent substrate for sedentary life. In many species, postlarval drifting typically lasts longer than the larval pelagic 
period; thus it may have greater dispersal potential and play an important role in determining the geographic distributions of adult populations. Dispersal may result in considerable changes in population dynamics and structure (Beukema \& de Vlas 1989, Armonies \& Hellwig-Armonies 1992). Beukema \& de Vlas (1989) suggested that all or nearly all Macoma balthica, an infaunal facultative deposit-feeding bivalve, in the North Sea probably originated from massive settlements of larvae on the high tidal flats in the Wadden Sea due to postlarval migration. Sigurdsson et al. (1976) first proposed that drifting was primarily driven by production of a byssus thread many times longer than the postlarval body size. Production of a drifting thread is common in many benthic invertebrates, including bivalves, gastropods and polychaetes (Butman 1987). Although there have been several laboratory and field studies on the drifting behavior of bivalve postlarvae (Lane et al. 1985, Yankson 1986, Beukema \& de Vlas 1989, Armonies 1992, Hooker 1995), the effects of environmental factors on the occurrence of this behavior are relatively little studied.

Sinonovacula constricta is an infaunal suspensionfeeding bivalve widely found in intertidal coastal and estuarine waters of China, Japan and Korea. It is also an important commercial bivalve in southern China (e.g. Fujian Province). In contrast to many other bivalves, the pelagic larval stage of $S$. constricta is relatively short (ca 6 to $10 \mathrm{~d}$ ) and thus has a relatively high larval survival rate (Qi 1986). However, high mortality is often associated with the culture of postlarvae in the field due to predation, disease and weather Migration of the settled juveniles also represents one of the greatest loss terms of its population from the cultivation areas. Various techniques have been developed to prevent the migration of postlarvae, but there are essentially no experimental studies of this behavior in S. constricta (Dalian College of Aquaculture 1980).

The behavioral responses of Sinonovacula constricta larvae to gravity, light and pressure were systematically investigated by Wang \& Xu $(1990,1993)$ and Xu \& Wang (1990). In this study, we measured the swimming velocity of larvae and the drifting behavior of postlarvae due to byssus thread secretion. The influences of different factors (temperature, light, age, starvation) on the occurrence of this behavior were also studied under controlled laboratory conditions. Such information can be used for understanding postlarval behavior in the natural environment.

\section{MATERIALS AND METHODS}

Spawning and culturing of larvae and postlarvae. Adult Sinonovacula constricta were collected from an intertidal mudflat in Ronhai County, Fujian, China, in October and November during their spawning season. Upon arrival in the laboratory, the animals were kept at $4^{\circ} \mathrm{C}$ (without seawater) for $4 \mathrm{~h}$, before being returned to a flow-through recirculating seawater aquarium. Spawning occurred within a few hours in the recirculating aquarium. Fertilized eggs were then collected by a $63 \mu \mathrm{m}$ nylon mesh and placed into $2 \mathrm{l}$ of $0.45 \mu \mathrm{m}$ membrane-filtered seawater at a density of 5 to 10 eggs $\mathrm{ml}^{-1}$. Experimental temperature and salinity were $25^{\circ} \mathrm{C}$ and $15 \mathrm{ppt}$, respectively. Light intensity was $4800 \mathrm{~lx}$ with a cycle of $12 \mathrm{~h}$ light:12 h dark. After $1 \mathrm{~d}$, the developed larvae were collected, maintained at a density of 2 to 5 larvae $\mathrm{ml}^{-1}$ and fed a mixed phytoplankton diet of Chaetoceros calcitrans and Dictrateria zhanjiangenis. The water was changed and food added every $2 \mathrm{~d}$.

After 6 to $7 \mathrm{~d}$ of pelagic life, larvae had undergone metamorphosis and developed into the postlarval stage (generally with $>90 \%$ survival rate). The postlarvae were maintained under the same experimental conditions as the larval culture, but at higher food concentrations. Qi (1984) classified the development of Sinonovacula constricta postlarvae into 3 different stages, including an early (without siphon), singlesiphon (inhalant) and double-siphon (both inhalant and exhalant) postlarval (= juvenile) stages. This classification was used in our study to distinguish various postlarval developmental stages.

Measurements of swimming velocity of larvae. Larvae exhibited both spiral upward and downward movements in a cylindrical helix with intermittent sinking. According to Cragg (1980), the instantaneous linear velocity $\left(U_{1}, \mathrm{~mm} \mathrm{~s}^{-1}\right)$ and the vertical velocity or absolute velocity $\left(U_{\mathrm{a}}, \mathrm{mm} \mathrm{s}^{-1}\right)$ of larval swimming can be calculated, respectively, by the following equations:

$$
\begin{gathered}
U_{\mathrm{i}}=\frac{H\left[\lambda_{b}{ }^{2}+\left(\pi \mathrm{D}^{2}\right)\right]^{1 / 2}}{T \lambda_{\mathrm{h}}} \\
U_{\mathrm{a}}=H / T
\end{gathered}
$$

where $H$ is the vertical distance that a larva traveled $(\mathrm{mm}), \lambda_{\mathrm{h}}$ is the height of 1 complete spiral (mm), D is the diameter of the helix ( $\mathrm{mm}$ ), and $T$ is the travel time (s). The pitch of the spiral (the angle of a tangent to the path) can also be calculated by:

$$
\tan \theta=\lambda_{h} /(\pi \mathrm{D})
$$

It was difficult to measure these parameters simultaneously for the same individual larva. The diameter of the helix (D) was measured under a Reverse Nikon Microscope with an eyepiece graticule while larvae were held in $50 \mathrm{ml}$ of water in a glass beaker. At least 20 individual measurements were taken and the mean of $\mathrm{D}$ was used to calculate $U_{1}$. To determine $H$ and $\lambda_{h}$, larvae were placed in a glass cylinder (diameter 
$8.5 \mathrm{~cm}$ ) containing $2000 \mathrm{ml}$ seawater. Food concentrations in seawater were 2000 to 5000 cells $\mathrm{ml}^{-1}$. Measurements were made 2 to $3 \mathrm{~h}$ after larvae were transferred into the cylinder. These measurements included the distance that a larva ascended or descended (read from the markers on the cylinder) during time $T$ (monitored by a stop watch), and the number of spirals executed. Generally, recordings were terminated when the larva began to sink (after at least 6 helical swimming rotations). Larvae were then fixed in $1 \%$ formalin and their shell lengths determined.

Sinking rates of formalin-killed larvae were also quantified by gently introducing them into a cylinder (diameter $8.5 \mathrm{~cm}$, length $42 \mathrm{~cm}$ ) containing $2000 \mathrm{ml}$ seawater. Sinking rates were measured when larvae reached the lower middle section of the cylinder. Sinking distance was read from the markers on the cylinder and the time was recorded by a stopwatch.

Observations of postlarval drifting behavior. Postlarvae were able to climb the glass wall and float on the water surface after ca $1 \mathrm{wk}$ of development. Both foot byssus and drifting thread were found at this stage (as observed by a Reverse Nikon Microscope). The sinking rates of drifters (with thread), non-drifters (without thread) and formalin-killed juveniles were determined by introducing them gently into $2000 \mathrm{ml}$ of water in a glass cylinder, as described above for larvae.

Factors affecting the postlarval drifting behavior. Age: On Day 2 of postlarval drifting (or Day 10 after larval settlement), 80 individuals (shell length 0.55 to $0.90 \mathrm{~mm}$ ) were placed into $500 \mathrm{ml}$ membrane-filtered seawater in a glass beaker. Mixtures of algal diets (Chaetoceros Calcitrans and Dictrateria zhanjiangenis) were added at a density of 50000 cells $\mathrm{ml}^{-1}$ and later increased to 200000 cells $\mathrm{ml}^{-1}$. Temperature and salinity of seawater were maintained as before. Light intensity was $1500 \mathrm{~lx}$ with a $12 \mathrm{~h}$ light: $12 \mathrm{~h}$ dark cycle. The number of juveniles climbing on the glass wall (e.g. remaining on the wall by thread attachment) and floating on the water surface were recorded every $2 \mathrm{~d}$. Dead individuals were also recorded and removed. Water was changed and algal food added every $2 \mathrm{~d}$ and any individuals attached to the wall were returned to the bottom. After $20 \mathrm{~d}$, juveniles were split into 2 groups and maintained under the same conditions. This experiment lasted $30 \mathrm{~d}$ until no drifting behavior was observed.

Temperature and light intensity: Postlarvae grown under normal experimental conditions $\left(25^{\circ} \mathrm{C}\right.$ and $\left.1500 \mathrm{~lx}\right)$ were maintained at different temperatures $\left(20,25\right.$, and $\left.30^{\circ} \mathrm{C}\right)$ and light intensities $(2400,800$, and $0 \mathrm{~lx})$. In each group, there were 50 individuals $(0.55$ to $0.90 \mathrm{~mm})$ in $250 \mathrm{ml} 15 \mathrm{ppt}$ seawater. Other conditions were similar to those in the age experiment described above.

Starvation: Postlarvae of 1.0 to $1.8 \mathrm{~mm}$ were divided into 2 groups: the fed group, with a normal feeding regime (algal mixtures of Chaetoceros calcitrans and Dictrateria zhanjiangenis), and the starved group, without algal food additions (in $0.45 \mu \mathrm{m}$ membrane-filtered seawater). There were 25 individuals in each group. Other conditions were similar to those in the age experiment.

\section{RESULTS}

\section{Swimming behavior and velocity of larvae}

The veliger larvae swam vertically in a clockwise cylindrical helix. A few individuals also swam in an anticlockwise direction. The central elongated flagellates in the velum pointed directly toward swimming direction. Generally, larval swimming alternated between a spiral upward or downward movement and then a sinking during which the velum either retracted or protruded outside the shell valves (but with weakened ciliary beating). At pediveliger stage, most larvae remained near the bottom of the water and were unable to modify their position in the water column by swimming due to their enlarged shells. Under these circumstances larvae would sink to the bottom and ascend slowly after a brief contact with the bottom.

The swimming velocities of 2 sizes of larvae (veliger and veliconcha stages) are shown in Table 1 . Both the downward and upward swimming velocities of veliger larvae $(133 \mu \mathrm{m})$ were comparable, suggesting that swimming at this stage was little affected by gravity. For veliconcha larvae $(180 \mu \mathrm{m})$, however, the upward swimming was slower than the downward swimming, primarily due to the enlargement of shells.

The sinking rate of larvae increased with larval development (Fig. 1). In general, larval sinking rate was greater than the swimming velocity, especially for older larvae. During larval swimming, the drag force of

Table 1. Sinonovacula constricta. Swimming velocity of 2 size classes of larvae $U_{1}$ : instantaneous linear velocity $\left(\mathrm{mm} \mathrm{s}^{-1}\right), U_{\mathrm{d}}$ : absolute velocity $\left(\mathrm{mm} \mathrm{s}^{-1}\right), \theta$ : pitch of the spiral $\left({ }^{\circ}\right.$ ). For calculation of each parameter, see 'Materials and methods' Mean $\pm \operatorname{SD}(n=15)$

\begin{tabular}{|cccccccc|}
\hline $\begin{array}{c}\text { Size } \\
(\mu \mathrm{m})\end{array}$ & $U_{1}$ & $\begin{array}{c}\text { Upward } \\
U_{\mathrm{a}}\end{array}$ & $\theta$ & $U_{1}$ & $U_{\mathrm{a}}$ & $\theta$ \\
\hline 133 & $0.48 \pm 0.16$ & $0.45 \pm 0.17$ & $62 \pm 13$ & $0.47 \pm 0.15$ & $0.42 \pm 0.16$ & $32 \pm 9$ \\
180 & $0.41 \pm 0.15$ & $0.35 \pm 0.15$ & $34 \pm 13$ & $0.69 \pm 0.22$ & $0.63 \pm 0.22$ & $39 \pm 8$ \\
\hline
\end{tabular}




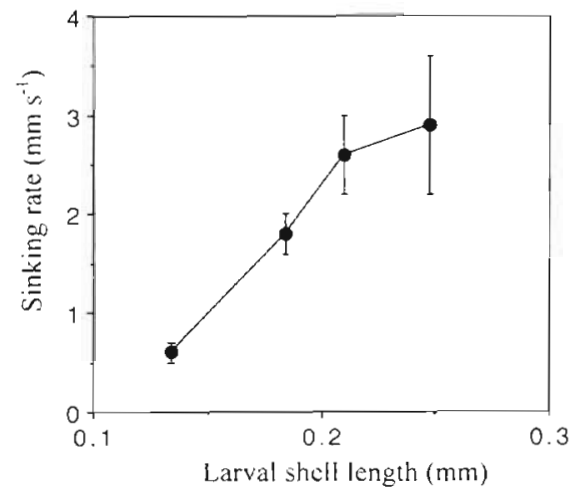

Fig. 1. Sinonovacula constricta. Sinking rates of different sizes of larvae. Mean $\pm \mathrm{SD}(\mathrm{n}=12)$

Table 2. Sinonovacula constricta. The relative density $(\delta-\rho)$ of 2 size classes of larvae, where $\delta$ is density of the animal and $\rho$ is density of seawater

\begin{tabular}{|cccc|}
\hline $\begin{array}{l}\text { Size } \\
(\mu \mathrm{m})\end{array}$ & $\begin{array}{c}\text { Sinking rate } \\
\left(\mathrm{mm} \mathrm{s}^{-1}\right)\end{array}$ & $\operatorname{Re}$ & $\begin{array}{c}(\delta-\rho) \\
\left(\mathrm{kg} \mathrm{m}^{-3}\right)\end{array}$ \\
\hline 133 & 0.66 & 0.096 & 63.02 \\
180 & 1.83 & 0.362 & 95.40 \\
\hline
\end{tabular}

body $\left(D_{\mathrm{b}}\right)$ is calculated by (Vogel 1994)

$$
D_{\mathrm{b}}=\frac{1}{2} C_{D} \rho A U^{2}
$$

where $C_{D}$ is the drag coefficient, $\rho$ is the density of seawater $\left(\mathrm{kg} \mathrm{m}^{-3}\right), A$ is the animal's cross-sectional area $\left(\mathrm{m}^{2}\right)$, and $U$ is the swimming velocity or larval sinking velocity $\left(\mathrm{m} \mathrm{s}^{-1}\right)$. The Reynolds number $(R e)$ is expressed as

$$
\operatorname{Re}=\rho / U / \eta
$$

where $l$ is the animal's length $(=2 a$, where $a$ is the radius of the animal, assuming that it is a sphere, in $\mathrm{m}$ ), and $\eta$ is the dynamic viscosity of seawater $\left(\mathrm{kg} \mathrm{m}^{-1} \mathrm{~s}^{-1}\right)$. When the $R e$ is $<0.5$, drag can be derived directly from Stokes' law (Vogel 1994)

$$
D_{\mathrm{b}}=6 \pi U_{\mathrm{a}} \eta
$$

Table 3. Sinonovacula constricta. The calculated velum propulsive force and the proportion of total energy spent on larval swimming activity. $F$ : velum propulsive force; $Q_{s}$ : energy spent in larval swimming; $Q$ : total energy expenditure $(Q$ values were taken from measurements of mussel larvae; Wang \& Widdows 1991)

\begin{tabular}{|ccccccc|}
\hline $\begin{array}{c}\text { Size } \\
(\mu \mathrm{m})\end{array}$ & $\begin{array}{c}U_{1} \\
\left(\mathrm{~mm} \mathrm{~s}^{-1}\right)\end{array}$ & $\operatorname{Re}$ & $\begin{array}{c}F \\
(\mathrm{~N})\end{array}$ & $\begin{array}{c}Q_{\mathrm{s}} \\
\left(\mathrm{J} \mathrm{s}^{-1} \mathrm{larva}^{-1}\right)\end{array}$ & $\begin{array}{c}Q \\
\left(\mathrm{~J} \mathrm{~s}^{-1} \text { larva }\right.\end{array}$ & $Q_{\mathrm{s}} / Q$ \\
\hline 133 & 0.48 & 0.070 & $1.5 \times 10^{-9}$ & $7.3 \times 10^{-13}$ & $1.5 \times 10^{-9}$ & $4.8 \times 10^{-4}$ \\
180 & 0.41 & 0.081 & $4.0 \times 10^{-4}$ & $1.7 \times 10^{-12}$ & $2.1 \times 10^{-9}$ & $7.9 \times 10^{-4}$ \\
\hline
\end{tabular}

When the sinking reaches a terminal velocity, the forces (gravitational, $G$, buoyancy, $B$, and drag, $D_{\mathrm{b}}$ ) are at equilibrium, that is,

$$
6 \pi U a \eta=\frac{4}{3} \pi a^{3}(\delta-\rho) g
$$

where $\delta$ is the animal's density $\left(\mathrm{kg} \mathrm{m}^{-3}\right)$ and $g$ is the gravitational acceleration $\left(9.8 \mathrm{~m} \mathrm{~s}^{-2}\right)$. The relative density $(\delta-\rho)$ is

$$
(\delta-\rho)=\frac{9 U \eta}{2 g a^{2}}
$$

The calculated $(\delta-\rho)$ of 2 size classes of larvae (133 and $180 \mu \mathrm{m}$ ) are shown in Table 2. At a seawater temperature of $25^{\circ} \mathrm{C}$ and salinity of $15 \mathrm{ppt}$, the $\rho$ is $1.0098 \mathrm{~kg} \mathrm{~m}^{-3}$, and $\eta$ is $9.916 \times 10^{-4} \mathrm{~kg} \mathrm{~m}^{-1} \mathrm{~s}^{-1}$. During larval upward swimming, the vertical component of velar propulsive force $\left(F_{\mathrm{v}}\right)$ is the sum of $D_{\mathrm{b}}$ and $(G-B)$. Thus:

$$
F_{v}=6 \pi U a \eta+\frac{4}{3} \pi a^{3}(\delta-\rho) g
$$

The ciliary beating is generally perpendicular to the velum (Cragg 1980, Chia et al, 1984). The largest angle between the velum protrusion and the vertical swimming direction was estimated to be about $30^{\circ}$ (measured under the Nikon Reverse Microscope). Thus the maximum total propulsive force of the velum is $F=F_{v} / \cos \left(30^{\circ}\right)$ or $F_{v} / 0.866$. The energy expenditure rate of velum propulsion is calculated to be $F \times U$. We then calculated the proportion of energetic cost of larval swimming activity to the total energy expenditure. Because there were no direct measurements of the metabolic rates of Sinonovacula constricta larvae, we used the metabolic rates of mussel larvae Mytilus edulis in our calculations (Wang \& Widdows 1991) (Table 3). The energetic costs due to velum propulsion and cilia beating were negligible compared to the total energy metabolism. The calculated proportion of energy spent on larval swimming also increased with larval development.

\section{Postlarval drifting behavior}

After ca 1 wk of development, the postlarvae secreted a single smooth byssus with a length of about $90 \mu \mathrm{m}$ and a diameter of $2.5 \mu \mathrm{m}$, which could be observed under the microscope when they crawled on the bottom of the beaker. From scanning electron microscopy (SEM) observations, the byssus extended from a small hole on the ventral part of the front foot (pho- 
tograph not shown). We first observed that postlarvae of Sinonovacula constricta were able to drift on Day 9 after settlement, in which they either climbed on the glass wall or floated on the water surface. The minimum size of drifting postlarvae was $0.4 \mathrm{~mm}$, whereas the maximum size was $2.3 \mathrm{~mm}$ which was recorded on Day 32 after larval settlement. The appearance of a drifting thread, much longer than the byssus, occurred several days later than the byssus secretion. It was difficult to quantify accurately the full length of thread, but we measured a length of $3.2 \mathrm{~cm}$ for a climbing individual of $0.5 \mathrm{~mm}$. The diameter of the thread was about 3 to $4 \mu \mathrm{m}$. The drifting thread appeared to be secreted from a small hole in the foot base (both SEM and microscopy observations, photograph not shown). The climbing individuals were apparently attached to the glass wall using an elongated thread, which could be easily checked when using a needle to lift the animal. For most floating individuals, the foot retracted within the shells while the single siphons protruded downward. Most individuals, apparently aided by the drifting thread, were able to remain floating when the water surface was gently disturbed.

The sinking rates of drifters (with thread), nondrifters (without thread) and formalin-killed juveniles are shown in Fig. 2. Sinking speeds of drifters were about 1 order of magnitude lower than the non-drifters or formalin-killed juveniles, but speeds were comparable between the non-drifters and the formalin-killed juveniles. When the postlarvae reach a terminal sinking velocity, their drag is equal to the difference of gravitational force to buoyancy force $(G-B)$. When $\operatorname{Re}>0.5$, Eq. (4) is used to calculate the drag. Thus

$$
\frac{1}{2} C_{D} \rho \pi a^{2} U^{2}=\frac{4}{3} \pi a^{3}(\delta-\rho) g
$$

$C_{13}$ is best described by the following equation when the Re $>0.5$ (Vogel 1994)

$$
C_{D}=\frac{24}{\operatorname{Re}}+\frac{6}{1+\operatorname{Re}^{1 / 2}}+0.4
$$

The $(\delta-\rho)$ of postlarvae was calculated from Eqs. (10) and (11) (Table 4). The viscosity drag of drifting thread $\left(D_{1}\right.$, with a length of $L$ and a diameter of $d$ ) when the postlarvae sink at a terminal velocity of $U$ is (Vogel 1994)

$$
D_{1}=\frac{2 \pi \eta U L}{\ln (L / d)-0.807}
$$

Assuming that the siphon withdraws within the shell valves during sinking, all forces are at equilibrium, including $G, B, D_{\mathrm{b}}$ and $D_{\mathrm{t}}$. That is,

$$
\frac{4}{3} \pi a^{3}(\delta-\rho) g=\frac{1}{2} C_{D} \rho \pi a^{2} U^{2}+\frac{2 \pi \eta U L}{\ln (L / d)-0.807}
$$

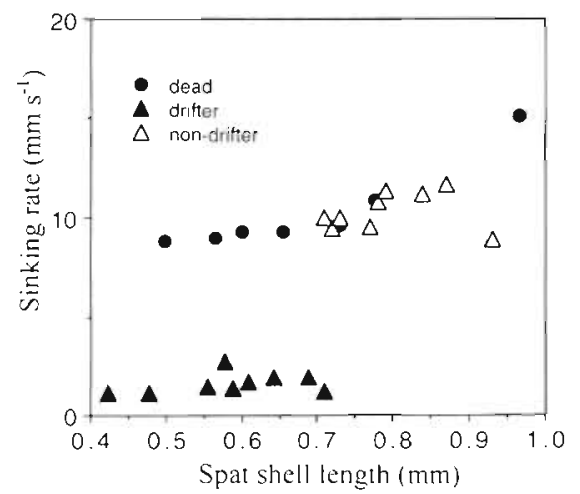

Fig. 2. Sinonovacula constricta. The sinking rates of drifting juveniles (with thread), non-drifting juveniles (without thread) and formalin-killed juveniles

The $C_{D}$ is calculated from Eq. (11) when $\operatorname{Re}>0.5$. The mean of postlarval $(\delta-\rho)$ is taken from Table 4 and the $d$ is assumed to be $3 \mu \mathrm{m}$. Calculations of the theoretical length of drifting thread $(L), D_{\mathrm{l}} / D_{\mathrm{b}}$ and $D_{\mathrm{t}} /(G-B)$ are shown in Table 5. Thus, the calculated theoretical values of $L$ are on the same order of magnitude as the actual measurements (i.e. $3.2 \mathrm{~cm}$ for a $0.5 \mathrm{~mm}$ individual). It is clear that to maintain the postlarvae in the water column $L$ should also increase dramatically with shell length. The predicted $D_{l}$ is $>6.7$ times greater than the $D_{\mathrm{b}}$ and can account for $86 \%$ of the $(G-B)$, therefore providing an important hydrodynamic basis for postlarval drifting

We also calculated the possible role of the siphon in postlarval drifting. Fig. 3 shows the relationship between the inhalant siphon length (fully protruded position) and the shell size. Thus the siphon length for a $0.610 \mathrm{~mm}$ individual was calculated as $0.298 \mathrm{~mm}$, with a diameter of $0.062 \mathrm{~mm}$ (measured under the microscope). Using Eq. (13), the ratio of viscosity drag by siphon to $D_{\mathrm{b}}$ is 0.57 , and to $(G-B)$ is 0.097 , suggesting that the siphon has minor role in maintaining juve-

\begin{tabular}{|c|c|c|c|c|}
\hline $\begin{array}{l}\text { Size } \\
(\mathrm{mm})\end{array}$ & $\begin{array}{c}\text { Sinkıng rate } \\
\left(\mathrm{mm} \mathrm{s}^{-1}\right)\end{array}$ & $\mathrm{Re}$ & $C_{I}$ & $\begin{array}{c}(\delta-\rho) \\
\left(\mathrm{kg} \mathrm{m}^{-3}\right)\end{array}$ \\
\hline 0.499 & 8.77 & 4.80 & 7.27 & 86.64 \\
\hline 0.566 & 8.93 & 5.55 & 6.51 & 70.90 \\
\hline 0.655 & 9.26 & 6.66 & 5.68 & 57.45 \\
\hline 0.777 & 10.87 & 9.27 & 4.47 & 52.54 \\
\hline 0.966 & 15.15 & 16.07 & 3.09 & 56.78 \\
\hline & & & \multicolumn{2}{|c|}{$\begin{array}{r}\text { Mean } 64.86 \\
\text { SD } 12.51\end{array}$} \\
\hline
\end{tabular}
niles in the water column.

Table 4. Sinonovacula constricta. The calculated relative density $(\delta-\rho)$ of postlarvae. $C_{D}$ : drag coefficient 


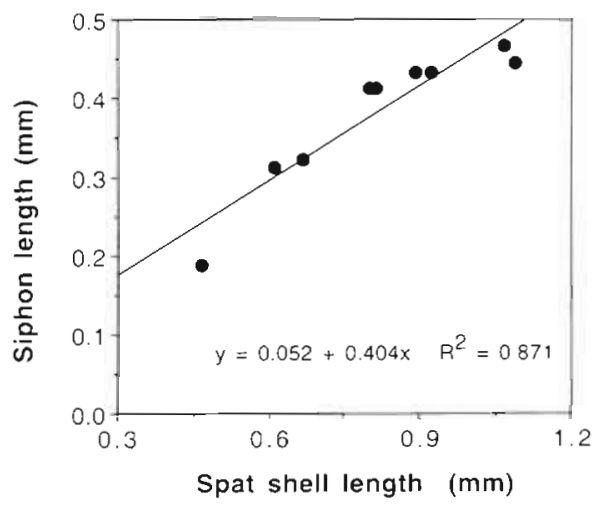

Fig. 3. Sinonovacula constricta. The relationship of inhalant siphon length to juvenile shell length. Siphon length was measured when it was in a fully protruded position

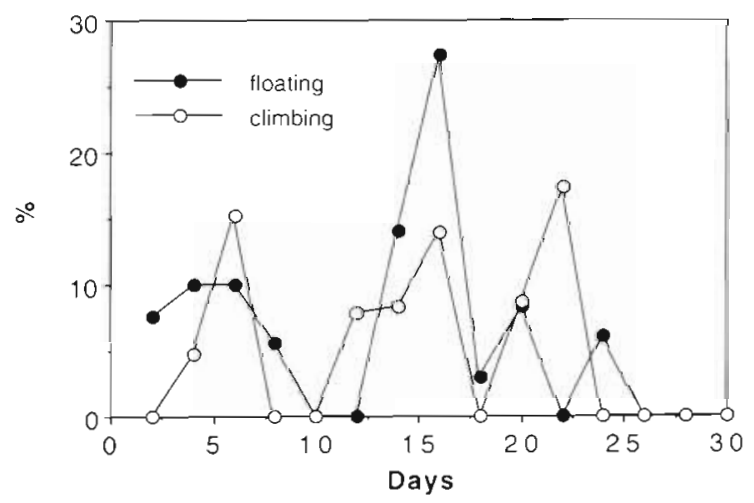

Fig. 4. Sinonovacula constricta. Changes in the frequency of postlarval climbing and floating during the course of the experiment

\section{Factors affecting postlarval drifting}

Age. Both climbing and floating rates fluctuated considerably during the course of experiments (Fig. 4). The highest frequency $(27 \%)$ of floating was observed on Day 16 (age 26 d after larval settlement) There were 3 peaks of postlarval climbing, including Days 6 $(15 \%), 16(14 \%)$, and $22(17 \%)$ (ages 16,26 , and $32 \mathrm{~d}$, respectively). On Day 22, the largest climbing individuals were $2.3 \mathrm{~mm}$. Both climbing and floating behavior disappeared after $26 \mathrm{~d}$. The total drifting rates (sum of climbing and floating rates) also exhibited 3 distinct peaks (Days 6, 16, and 22), especially on Day 16 (41. \%).

Temperature. Both climbing and floating rates were lower at $30^{\circ} \mathrm{C}$ than at 20 or $25^{\circ} \mathrm{C}$ (Fig. 5). At $20^{\circ} \mathrm{C}$, climbing rates increased appreciably after $8 \mathrm{~d}$, indicating that lowered temperature enhanced postlarval climbing. However, floating rates at $20^{\circ} \mathrm{C}$ were lower than the controls $\left(25^{\circ} \mathrm{C}\right)$ between Days 4 and 8 . In general, high temperatures $\left(30^{\circ} \mathrm{C}\right)$ inhibited postlarval drifting, whereas enhancement of drifting at lowered temperature was apparent after $8 \mathrm{~d}$. By the end of experiment, there was no significant difference in postlarval shell length among the 3 temperature treatments.

Light intensity. There was little evidence to indicate that light levels affected postlarval drifting behavior within the first $6 \mathrm{~d}$ (Fig. 6). After $6 \mathrm{~d}$, drifting increased appreciably at lowered light illumination (including dark). At $800 \mathrm{~lx}$, climbing rate was as high as $36.5 \%$ on Day 14 , the highest rate recorded among all experiments.

Starvation. Starvation induced postlarval drifting, especially floating behavior (Fig. 7). Floating in fed individuals was undetectable during the experiments. Climbing rates in starved individuals were higher than in the fed individuals after $2 \mathrm{~d}$ of starvation. Nearly all starved individuals did not grow and, in contrast to the fed individuals whose digestive tracts contained numerous food particles, their guts were found empty during the experiments.

\section{DISCUSSION}

\section{Larval swimming behavior and energetics}

Larval swimming behavior in Sinonovacula constricta was identical to that of other bivalve larvae (Bayne 1964b, Lough \& Gonor 1971, Cragg \& Gruffydd 1975, Cragg 1980, Mann \& 

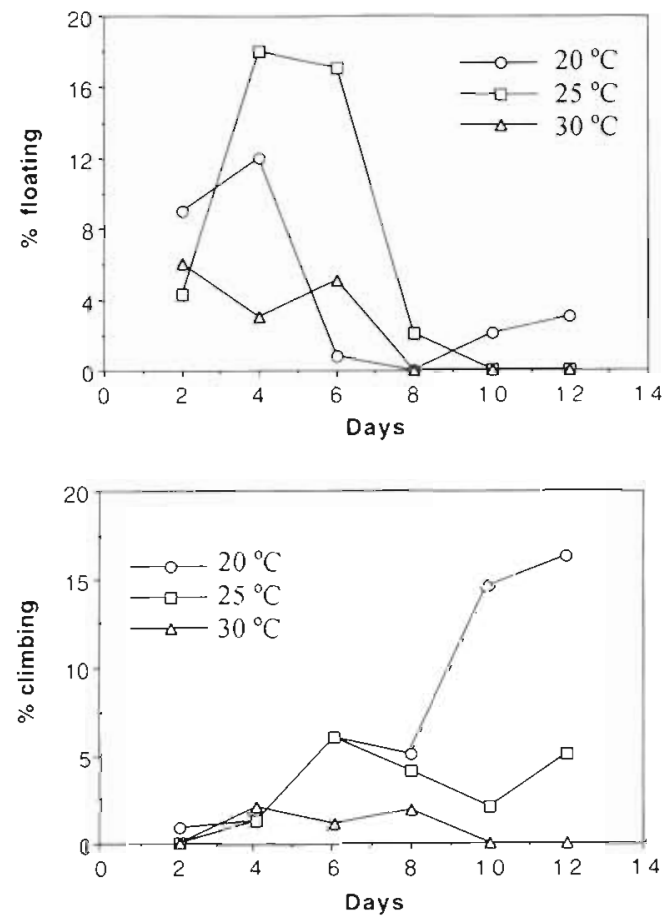

Fig. 5. Sinonovacula constricta. Changes in the percentages of postlarval climbing and floating with time at different temperatures $\left(20,25\right.$, and $\left.30^{\circ} \mathrm{C}\right)$
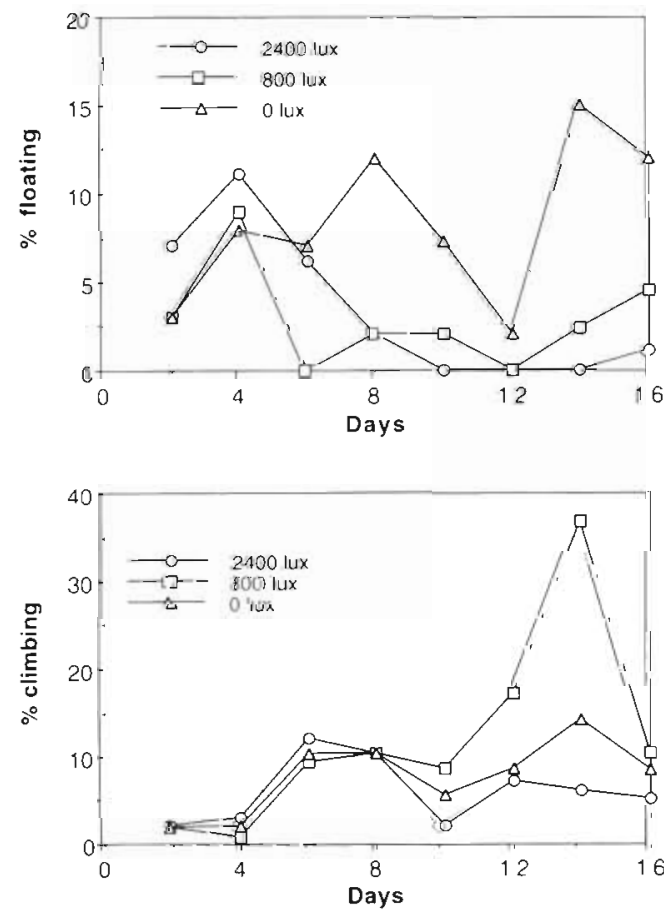

Fig. 6. Sinonovacula constricta. Changes in the percentages of postlarval climbing and floating with time at different light illumination
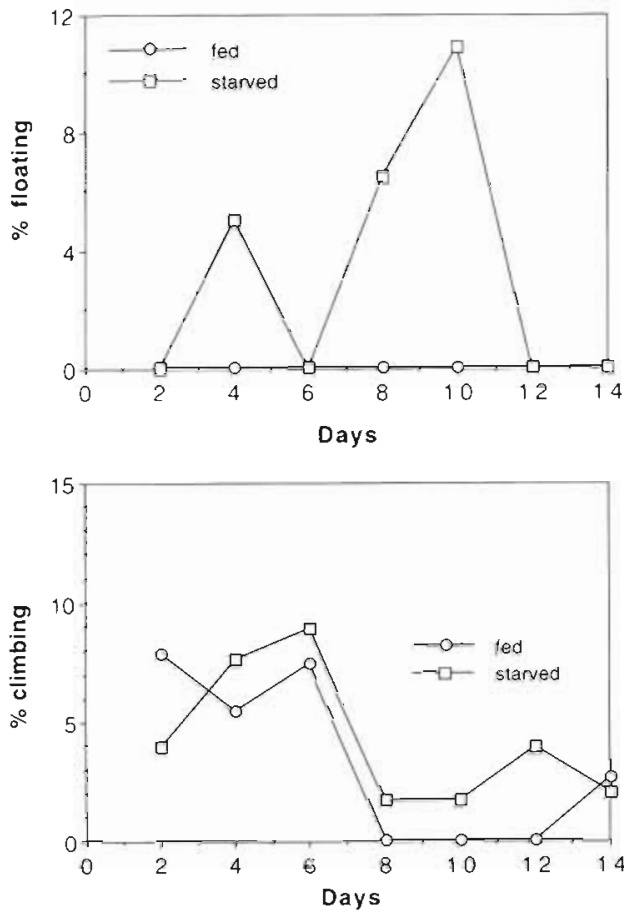

Fig. 7 Sinonovacula constricta. Changes in the percentages of postlarval clumbing and floating with time under fed and starved conditions

Wolf 1983, Zhang 1984, Mann et al. 1991, Jonsson et al. 1991), and was characterized by a vertically oriented helical spiral with intermittent sinking. Helical swimming is common among marine invertebrate larvae, but its implications are not yet well understood (Chia et al. 1984, Crisp 1984). Chia et al. (1984) suggested that helical swimming may facilitate larvae with a single sensory organ (e.g. statocyst) in detecting the presence of light and gravity. In addition, it may be possible for the larvae to control their swimming velocity and direction by changing the height and diameter of helix during their upward or downward movements.

The swimming velocities $\left(0.3\right.$ to $\left.0.7 \mathrm{~mm} \mathrm{~s}^{-1}\right)$ of Sinonovacula constricta larvae were directly comparable to the values reported in other bivalve larvae (Table 6). However, comparison of swimming rates among different studies may be difficult because of the lack of consistency in both experimental methods and data presentation (Mann et al. 1991). The downward swimming speed exceeded the upward swimming speed as $S$. constricta veliger larvae developed to the veliconcha stage, in contrast to other bivalve larvae in which both speeds were comparable for the veliger and veliconcha larvae (e.g. Spisula solidissima, Mulinia lateralis, Rangia cuneata, Mann et al. 1991; Crassostrea gigas, Wang \& Xu unpubl.). Mann et al. (1991) also found that the upward swimming rate decreased as larvae developed into the pediveliger 
Table 6. Comparisons of swimming velocity of marine bivalve larvae. For upward and downward swimming, only the vertical velocities are included

\begin{tabular}{|c|c|c|c|c|c|c|}
\hline \multirow{2}{*}{ Species } & \multirow[t]{2}{*}{ Larval stage } & \multicolumn{4}{|c|}{ Swimming velocity $\left(\mathrm{mm} \mathrm{s}^{-1}\right)$} & \multirow[t]{2}{*}{ Source } \\
\hline & & Upward & Downward & Horizontal & Unspecified & \\
\hline Arctica islandica & Various stages & & & & $0.28-0.37$ & Mann \& Wolf (1983) \\
\hline Cerastoderma edule & Pediveliger & 0.91 & 1.3 & & & Jonsson et a]. (1991) \\
\hline Crassostrea gigas & $\begin{array}{l}\text { Veliger } \\
\text { Veliconcha }\end{array}$ & $\begin{array}{l}0.86 \\
1.71\end{array}$ & $\begin{array}{l}0.84 \\
1.51\end{array}$ & & & Wang \& Xu (unpubl.) \\
\hline Crassostrea virginica & $\begin{array}{l}\text { Veliger } \\
\text { Pediveliger }\end{array}$ & & & $\begin{array}{c}0.1-0.8 \\
0.8\end{array}$ & & Hidu \& Haskin (1978) \\
\hline Mulinia lateralis & $\begin{array}{l}\text { Veliger } \\
\text { Veliconcha }\end{array}$ & $\begin{array}{l}0.25-0.43 \\
0.25-0.50\end{array}$ & $\begin{array}{l}0.22-0.49 \\
0.37-0.52\end{array}$ & & & Mann et al. (1991) \\
\hline Mytilus edulis & Veliconcha & & & $1.2-3.3$ & & Sprung (1984) \\
\hline Ostrea edulis & Veliconcha & & & & 1.2 & Cragg \& Gruffydd (1975) \\
\hline Pecten maximus & $\begin{array}{l}\text { Early veliger } \\
\text { Pediveliger }\end{array}$ & $\begin{array}{c}0.25-1.1 \\
0.4\end{array}$ & & & & Cragg $(1980)$ \\
\hline Pincatada margaritifera & $\begin{array}{l}\text { Veliger } \\
\text { Veliconcha } \\
\text { Eyed larvae }\end{array}$ & & & & $\begin{array}{l}0.38 \\
1.43 \\
2.89\end{array}$ & Zhang (1984) \\
\hline Rangia cuneata & $\begin{array}{l}\text { Veliger } \\
\text { Veliconcha }\end{array}$ & $\begin{array}{l}0.18-0.38 \\
0.36-0.50\end{array}$ & $\begin{array}{l}0.25-0.30 \\
0.53-0.57\end{array}$ & & & Mann et al. (1991) \\
\hline Sinonovacula constricta & $\begin{array}{l}\text { Veliger } \\
\text { Veliconcha }\end{array}$ & $\begin{array}{l}0.45 \\
0.35\end{array}$ & $\begin{array}{l}0.42 \\
0.63\end{array}$ & & & This paper \\
\hline Spicula solidissima & $\begin{array}{l}\text { Veliger } \\
\text { Veliconcha }\end{array}$ & $\begin{array}{l}0.19-0.26 \\
0.22-0.49\end{array}$ & $\begin{array}{l}0.15-0.18 \\
0.22-0.37\end{array}$ & & & Mann et al. (1991) \\
\hline
\end{tabular}

stage, primarily due to the changes in larval specific gravity and velar morphology. Both the instantaneous linear velocity (the velocity of a larva along its path) and the vertical velocity of $S$. constricta larvae measured in this study were similar; this is consistent with findings for Pecten maximus larvae (Cragg 1980). By contrast, Mann \& Wolf (1983) found that the vertical velocity (= absolute velocity) was ca 2 times greater than the linear velocity in the larvae of Arctica islandica.

By comparison to the vertical current flow in estuaries (e.g. $0.1 \mathrm{~mm} \mathrm{~s}^{-1}$, Wood \& Harris 1971), the higher larval swimming velocity suggests that bivalve larvae are able to regulate their vertical distributions in coastal and estuarine waters. However, horizontal transport of larvae is passive due to the lack of active horizontal swimming and the high physical current velocity. The combination of active vertical regulation and passive horizontal transport eventually determines if the larvae are to be retained within an estuary (Wood \& Harris 1971, Scheltema 1986). Jonsson et al. (1991) recently found that the pediveliger larvae of Cerastoderma edule were confined to the viscous sublayer $<1 \mathrm{~mm}$ above the sediment surface and slowly drifted in a streamwise direction at a flow of 5 to $10 \mathrm{~cm} \mathrm{~s}^{-1}$. When the flow was $>15 \mathrm{~cm} \mathrm{~s}^{-1}$, the steady drift changed to bedload transport of tumbling larvae with high probability of resuspension.
The swimming speeds of marine invertebrate larvae are generally measured in a small water container, in which the 'wall effect' may be a problem in overestimating larval swimming (Chia et al. 1984). For example, a larva dragged at a low Re number can accelerate abruptly when it reaches a surface which is a few hundred times bigger than its body size (Purcell 1977 , Vogel 1994). In our study, we also observed that larvae near the glass wall swam at a much faster rate (mostly linearly) than other larvae swimming away from the glass wall. This 'wall effect' can be estimated by calculating the viscous boundary thickness (White 1974):

$$
h=[2 \eta l /(\rho U)]^{1 / 2}
$$

where $h$ is the viscous boundary thickness. Calculations showed that $h$ was 0.71 and $0.89 \mathrm{~mm}$ for larvae of 133 and $180 \mu \mathrm{m}$, respectively. Thus measurements made at the mid-intersection of the cylinder (diameter of $8.5 \mathrm{~cm}$ ) were probably reflective of the actual swimming velocities of Sinonovacula constricta larvae.

Theoretical calculations indicated that the energetic cost of larval swimming was negligible compared to the total energy metabolism. It should be emphasized that these were indirect estimations, as no measurements of larval metabolic rates were taken for Sinonovacula constricta. Nevertheless, metabolic rates among marine bivalve larvae appear to be relatively constant, usually within an order of magnitude of variation $\left(1\right.$ to $10 \mathrm{ml} \mathrm{g}^{-1}$ 
dry wt $\mathrm{h}^{-1}$; Crisp 1984, Sprung 1984); thus the overall conclusions would not change considerably if the metabolic rates of $S$. constricta larvae were to be measured. Sprung (1984) similarly calculated that the swimming energetic cost was about $1 \%$ of total energy expenditure in mussel larvae. His calculation only considered the gravitational and buoyancy forces and ignored the viscosity drag, and may therefore have underestimated the energetic cost of swimming. In adult mussels, direct calorimetry also showed that the ciliary pumping activity represented a negligible fraction of total energy expenditure $(<3 \%$; Widdows \& Hawkins 1989).

\section{Postlarval drifting behavior}

Postlarvae of Sinonovacula constricta were able to secret a single drifting thread and resume pelagic life after ca $1 \mathrm{wk}$ of development. This is consistent with many studies in other marine bivalves and gastropods (Sigurdsson et al. 1976, de Blok \& Tan-Mass 1977. Lane et al. 1982, 1985, Board 1983, Yankson 1986. Cummings et al. 1993, Hooker 1995). Sigurdsson et al. (1976) first reported the production of drifting threads in at least 20 species of young postlarval bivalve molluscs and termed this mechanism 'byssus drifting' The thread can play an important role in pelagic drifting by directly increasing viscous drag (Sigurdsson et al. 1976. Lane et al. 1985). Our calculations indicated that the viscous drag of the drifting thread was at least 6.7 times greater than the drag of shell body, and accounted for $86 \%$ of the difference of gravitational force to buoyancy force. In mussels, Lane et al. (1985) estimated that the ratio of viscous thread force to shell drag force for postlarvae was between 6 and 38 , depending on the length of thread. The sinking rates (1 to $2 \mathrm{~mm} \mathrm{~s}^{-1}$ ) of $S$. constricta postlarval drifters were about an order of magnitude lower than those of the non-drifters, which is consistent with measurements in mussels (Lane et al. 1985). In the natural environment, an upward vertical current velocity of $1 \mathrm{~cm} \mathrm{~s}^{-1}$ would be sufficient to suspend drifting postlarvae in the water column (Sigurdsson et al. 1976). In this study, we also occasionally observed that the foot of $S$. constricta postlarvae wriggled extensively during sinking These measured sinking rates were appreciably lower than those of other sinking individuals whose foot was retracted within the shell. However, such a mechanism was not sufficient for postlarvae to remain in the water column (Sigurdsson et al. 1976). In addition, our calculations indicated that the role of the inhalant siphon in postlarval drifting is insignificant.

The largest body sizes of postlarval drifters recorded in the clams Cerastoderma glaucum and C. edule were 6.9 and $4.0 \mathrm{~mm}$, respectively (Yankson 1986). For these infaunal bivalves, an extended pelagic drifting period may enable them to be more selective in choosing substrates than postlarvae with a limited pelagic drifting period. In a field investigation, Armonies (1992) found that the drifting juvenile clams Macoma balthica and cockle $C$. edule collected in the tidal waters of the Wadden Sea were in the size range 0.7 to $4.0 \mathrm{~mm}$ and 0.5 to $3.5 \mathrm{~mm}$, respectively. The maximum size $(2.3 \mathrm{~mm})$ found in drifting postlarvae in Sinonovacula constricta was smaller than for these infaunal bivalves. but was comparable to those for epifaunal bivalves such as mussels $(<2.0$ to $2.5 \mathrm{~mm}$; de Block \& Tan-Maas 1977). Sigurdsson et al. (1976) also recorded that drifting occurred for pediveliger larvae to at least $2.5 \mathrm{~mm}$ in many bivalves. In $S$. constricta, the secondary drifting period is about $1 \mathrm{mo}$, and thus may play a far more important role in the selection of substrates for permanent settlement and in geographic distributions than does the relatively shorter pelagic life of the larval stage (about $1 \mathrm{wk}$ ).

The highest frequency of postlarval drifting in Sinonovacula constricta occurred within the first $35 \mathrm{~d}$, especially on Day 26 after larval settlement. Consistent with these laboratory observations, in an extensive field survey of $S$. constricta postlarvae in Ronhai, Fujian, massive postlarval migration was found by $\mathrm{B} .-\mathrm{X}$. Zhang (unpubl.) to occur within 15 to $20 \mathrm{~d}$ of larval settlement. Our results suggested that the secretion of a drifting byssus played a critical role in postlarval migration. Such migration would have a profound effect on population structure and dynamics, but this has not been investigated in the field. In Cerastoderma glaucum, postlarval climbing was found between age 30 and $42 \mathrm{~d}$, with a peak at age $37 \mathrm{~d}$ (Yankson 1986). A $10 \mathrm{~d}$ drifting periodicity not closely related to lunar phase was also observed in Macoma balthica in the Wadden Sea (Armonies 1992).

Very few studies have determined the effects of environmental factors on the postlarval drifting of bivalve. Yankson (1986) observed that following $3 \mathrm{~d}$ of starvation, juveniles (up to $15 \mathrm{~mm}$ ) of Cerastoderma glancum were able to climb up a glass wall, whereas fed individuals tended not to climb when they became older and larger Juveniles of Sinonovacula constricta also increased their drifting behavior in response to starvation stress. In this experiment, starved individuals were able to float on the water surface whereas no floating behavior was observed in fed individuals. However, these experimental results may also be confounded by the size differences between fed and starved individuals, as there was no growth for the starved individuals during the experiment. The increase in drifting in starved individuals will undoubtedly enable them to disperse to other areas where abundant food may be available. Our field surveys 
also indicated that juveniles of $S$. constricta living in sandy sediments were more likely to migrate to other areas, presumably due to food limitations. At lowered temperature, individuals of $S$. constricta tended to drift more frequently, as is consistent with findings in the clam Macoma balthica (Sörlin 1988). S. constricta spawns annually between October and November in the coastal and estuarine waters of Fujian (temperature about $25^{\circ} \mathrm{C}$ ). During the postlarval growth period, the seawater temperature decreases precipitously, which may have favored the postlarval drifting. The effects of light illumination on postlarval drifting were evident after $6 \mathrm{~d}$, when reduced light illumination enhanced drifting. It is not known whether these behavioral responses may account for the diurnal changes in postlarval drifting commonly observed in the field. For example, Armonies (1992) observed that the migratory activities of drifting bivalves and mud snails showed a strong diurnal pattern. Bivalves were more abundant in the water column in the dark than during daytime, whereas the reverse was true for the mud snail Hydrobia ulvae. Diurnal change in light illumination may be directly responsible for the migratory activities of drifting bivalves and gastropods.

Massive migrations of Sinonovacula constricta postlarvae are often recorded after heavy rains in estuarine regions in Southern China. In some cases it was observed that there were virtually no individuals remaining in the cultivation field. In fact, postlarval drifting induced by heavy rains is one of the most serious natural catastrophes (in addition to predation and diseases) for commercial harvesters. There are at least 2 possible mechanisms responsible for the loss of juveniles following heavy rains: (1) the erosion of surface sediment may directly expose postlarvae which are subsequently resuspended and carried by horizontal water currents and (2) the lowered salinity due to freshwater input may stimulate postlarval drifting. In our salinity experiment (results not shown due to high mortality in this experiment), there was a general tendency in which lowered salinity (e.g. 10 ppt) induced postlarval drifting. This salinity factor needs to be examined further

It should be emphasized that our observations of postlarval drifting of Sinonovacula constricta were performed in static water. Application of laboratory observations to nature may thus be confounded by current interaction. Currents can either resuspend the drifters (with thread) or induce the secretion of thread once the juveniles are resuspended in the water column. The importance of tidal current has also been documented in many field studies (Beukema \& de Vlas 1989, Armonies 1992, Hooker 1995, Thiébaut et al. 1996). Beukema \& de Vlas (1989) found that the highest numbers of drifting Macoma balthica juveniles were directly correlated with the maximum tidal current speed. When the current speed was very low, the juveniles apparently disappeared from the water column. Similarly, the abundance of polychaete Pectinaria koreni postlarvae in the water column varied strongly with the tide; maximum densities were observed after $2 \mathrm{~h}$ of tidal current maxima and mean densities were at least an order of magnitude greater during flood than during ebb (Thiébaut et al. 1996). Our preliminary results suggested that when the postlarvae were maintained in sediment in static waters, they exhibited far less ability to drift compared to postlarvae maintained without sediment. Therefore, both physical factors (e.g. tidal currents) and biological factors (e.g. thread production) are critical in determining the bysso-pelagic drifting in $S$. constricta in nature.

Acknowledgements. We dedicate this paper to the memory of our mentor, the late Professor Chong Cheng, who founded the researches on marine planktonology in China and passed away in August 1993. We are grateful to N. Craig, S. Griscom and the anonymous referees for their helpful and constructive comments on this work.

\section{LITERATURE CITED}

Armonies W (1992) Migratory rhythms of drifting juvenile molluscs in tidal waters of the Wadden Sea. Mar Ecol Prog Ser 83:197-206

Armonies W, Hellwig-Armonies M (1992) Passive settlement of Macoma balthica spat on tidal flats of the Wadden Sea, and its implications in distribution patterns. Neth J Sea Res 29:371-378

Bayne BL (1964a) Primary and secondary settlement in Mytilus edulis L. J Anim Ecol 33:513-523

Bayne BL (1964b) The response of the larvae of Mytilus edulis L. to light and gravity. Oikos 15:162-174

Beukema JJ, de Vlas J (1989) Tidal-current transport of thread-drifting postlarval juveniles of the bivalve Macoma balthica from the Wadden Sea to the North Sea. Mar Ecol Prog Ser 52:193-200

Board P (1983) The settlement of post-larval Mytilus edulis (settlement of post-larval mussels). J Molluscan Stud 49: $53-60$

Butman CA (1987) Larval settlement of soft sediment invertebrates: the spatial scales of pattern explained by active habitat selection and the emerging role of hydrodynamical processes. Oceanogr Mar Biol Annu Rev 25:113-165

Chia FS, Buckland-Nicks J, Young CM (1984) Locomotion of marine invertebrate larvae: a review. Can J Zool 62: $1205-1222$

Cragg SM (1980) Swimming behaviour of the larvae of Pecten maximus (L.) (Bivalvia). J Mar Biol Ass UK 60:551-564

Cragg SM, Gruffydd LID (1975) The swimming behaviour and the pressure responses of the veliconcha larvae of Ostrea edulis (L.). In: Barnes H (ed) Proc 9th European Mar Biol Symp. Aberdeen University Press, Aberdeen, $p$ $43-57$

Crisp DJ (1984) Overview of research on marine invertebrate larvae. In: Costlow JD. Tipper RC (eds) Marine biodeteri- 
oration: an interdisplinary study. Institute Press, Annapolis, MD, p 103-126

Cummings VJ, Pridmore RD, Thrush SF, Hewitt JE (1993) Emergence and floating behaviors of post-settlement juveniles of Macomona liliana (Bivalvia: Tellinacea). Mar Behav Physiol 24:25-32

Dalian College of Aquaculture (1980) Aquaculture of shellfish. Agriculture Press, Peking

De Blok JW. Tan-Maas M (1977) Function of byssus threads in young postlarval Mytilus. Nature 267:558

Hidu H, Haskın HH (1978) Swimmıng speeds of oyster larvae Crassostrea virginica in different salinities and temperatures. Estuaries 1:252-255

Hooker SH (1995) Preliminary evidence for post-settlement movement of juvenile and adult pipı, Paphies australss (Gmelin, 1790) (Bivalvia: Mesodesmatidae). Mar Behav Physiol 27:37-47

Jonsson PR, André C, Lindegarth M (1991) Swimming behavior of marine bivalve larvae in a flume boundary-layer flow: evidence for near-bottom confinement. Mar Ecol Prog Ser 79:67-76

Lane DJW, Beaumont AR, Hunter JR (1985) Byssus drifting and the drifting threads of the young post-larval mussel Mytilus edulis. Mar Biol 84:301-308

Lane DJW, Nott JA, Crisp DJ (1982) Enlarged stem glands in the foot of the post-larval mussel, Mytilus edulis: adaptation for bysso-pelagic migratıon. J Mar Biol Ass UK 62: $809-818$

Lough RG, Gonor JJ (1971) Early embryonic stages of Adula californiensis (Pelecypoda: Mytilidae) and the effect of temperature and salinity on development rate. Mar Biol 23:11-17

Mann R (1988) Distribution of bivalve larvae at a frontal system in the James River, Virgunia. Mar Ecol Prog Ser 50:29-44

Mann R, Campos BM, Luckenbach MW (1991) Swimming rate and responses of larvae of three mactrid bivalves to salinity discontinuties. Mar Ecol Prog Ser 58:257-269

Mann R, Wolf CC (1983) Swimming behavior of larvae of the ocean quahog Arctica islandica in response to pressure and temperature. Mar Ecol Prog Ser 13:211-218

Mileikovsky SA (1973) Speed of active movement of pelagic larvae of marine bottom invertebrates and their ability to regulate their vertical position. Mar Biol 23:11-17

Purcell FM (1977) Life at low Reynolds numbers. Am J Phys 45:1-11

Qi C (1986) The growth and development of the pelagic larvae, spat and juveniles in Sinonovacula constricta. Taiwan Strait 3:90-99 (in Chinese)

Thas article was submitted to the editor
Scheltema RS (1986) On dispersal and planktonic larvae of benthic invertebrates: an eclectic overview and summary of problems. Bull Mar Sci 39:290-322

Sigurdsson JB, Titman CW, Davies PA (1976) The dispersal of young post-larval bivalve molluscs by byssus threads Nature 262:386-387

Sörlin Y (1988) Floating behavior of the tellinid bivalve Macoma balthica (L.) Oecologia 77:273-277

Sprung M (1984) Physiological energetics of mussel larvae, Mytilus edulis. lli. Respiration. Mar Ecol Prog Ser 18: $171=178$

Sulkin SD (1984) Behavioral basis of depth regulation in the larvae of brachyuran crabs. Mar Ecol Prog Ser 15:181-205

Thiébaut E, Dauvin JC, Wang Z (1996) Tidal transport of Pectinaria koreni postlarvae (Annelida: Polychaeta) in the Bay of Seine (eastern English Channel). Mar Ecol Prog Ser 138:63-70

Thorson G (1950) Reproductive and larval ecology of marine bottom invertebrates. Biol Rev 25:1-34

Vogel S (1994) Life in moving fluids, 2nd edn. Princeton University Press, Princeton, NJ

Wang WX, Widdows J (1991) Physiological responses of mussel larvae Mytilus edulis to environmental hypoxia and anoxia. Mar Ecol Prog Ser 70:223-236

Wang WX, Xu ZZ (1990) Influences of environmental factors on the taxic behavior of two marine bivalve larvae. Acta Ecol Sinica 10:237-242 (in Chinese)

Wang WX, Xu ZZ (1993) The pressure responses of the larvae of Sinonovacula constricta (Bivalvia). In: Chinese Society of Malacology (ed) Transactions of the Chinese Society of Malacology, Vol 4 Qingdao Ocean Univ Press, Qingdao, p 85-93 (in Chinese)

White FM (1974) Viscous flund flow. MaGraw-Hill, New York

Widdows J, Hawkins AJS (1989) Partitioning of rate of heat dissipation by Mytilus edulis into maintenance, feeding, and growth components. Physiol Zool 62:764-784

Wood L, Harns WJ (1971) Transport of bivalve larvae in a tidal estuary. In: Crisp DJ (ed) Proc 4th European Mar Biol Symp. Cambridge University Press, Cambridge, p 29-44

Xu ZZ, Wang WX (1990). On the taxic behavior of the larvae of Sinonovacula constricta. J Xiamen Univ (Natural Sci) 29:444-448 (in Chinese)

Yankson K (1986) Observations on byssus systems in the spat of Cerastoderma glaucum and C. edule. J Mar Biol Ass UK $66: 277-292$

Zhang $G$ (1984) The behavioral biology of the larvae of Pincatada margaritifera. In: Xie Y (ed) Studies in the tropical ocean. Ocean Press, Peking, p 121-147 (nn Chinese)

Manuscript first received: October 30,1996

Revised version accepted: January 20,1997 